\title{
Structural Performance and Finite Element Modeling of Roller Compacted Concrete Dams: A Review
}

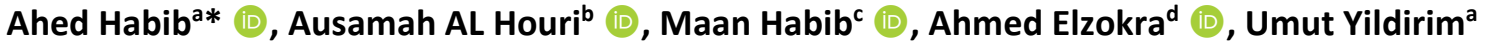 \\ ${ }^{a}$ Dept. of Civil Engineering, Eastern Mediterranean University, Famagusta, North Cyprus, via Mersin 10, Turkey. E-mail: \\ ahed.habib@cc.emu.edu.tr, umut.yildirim@emu.edu.tr \\ ${ }^{b}$ Dept. of Civil Engineering, Near East University, Nicosia, North Cyprus, via Mersin 10, Turkey. E-mail: osama.houri@gmail.com \\ ${ }^{c}$ Dept. of Civil Engineering, Al-Balqa Applied University, Amman, Jordan. E-mail: maan.habib@bau.edu.jo \\ d Dept. of Civil Engineering, Alma Mater Studiorum - Bologna University, Bologna, Italy. E-mail: ahmed.elzokra@gmail.com \\ * Corresponding author
}

https://doi.org/10.1590/1679-78256467

\begin{abstract}
There is no doubt that concrete is one of the most consumed materials all over the world. It is a composite mix widely used for constructing structures and infrastructures to sustain environmentally induced stresses such as thermal and seismic. As the mainstream of construction industry is tended to find out feasible solutions, Roller Compacted Concrete (RCC) was introduced to play an essential role in the development of dams and pavements, where over 550 RCC dams were created by the end of 2012. In fact, this material has the same basic constituents of conventional concrete with a zero-slump and a significant difference in the placing process. The majority of available studies in the literature are composed of numerical investigations to assess the thermal and seismic behavior of RCC dams and to provide a clear view on how to improve its performance under various loading conditions. This paper summarizes and compares the general conclusions of recent works on evaluating the structural performance of RCC dams.
\end{abstract}

\section{Keywords}

Roller compacted concrete, dams, numerical analysis, finite element modeling, thermal stress, seismic behavior

\section{Graphical abstract}

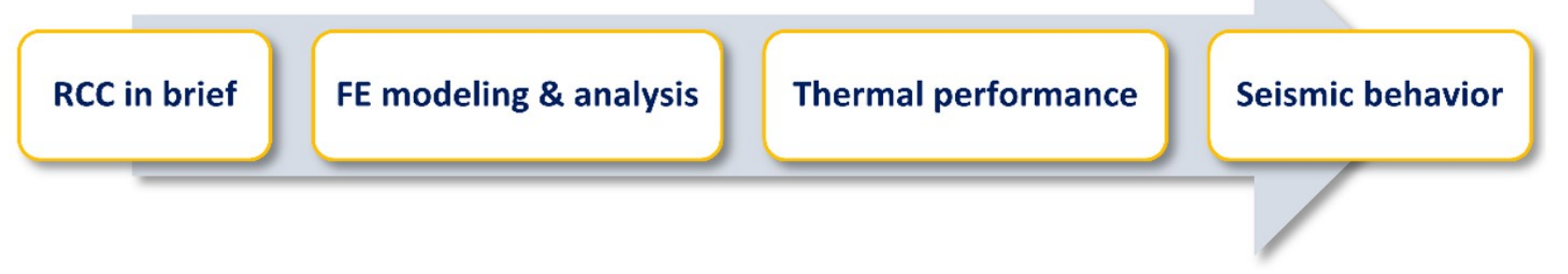




\section{INTRODUCTION}

Throughout history, people have paid great attention to building dams across a river to establish a reservoir in the valley based on the topography. Dam as a vital facility plays different significant roles in providing a wide range of economic, environmental, and social benefits such as flood control, water supply, hydroelectric power, and so on. Consequently, great care should be taken in the design, evaluation, and implementation of a dam to ensure its effectiveness, safety, stability, and reduce the risks of catastrophic failures (Gharibdoust et al., 2019). Nowadays, roller compacted concrete (RCC) dam has a promising future due to its fast construction process, low engineering cost, strong environmental adaptability, and good control of heat generation (Hu et al., 2019; Huang \& Wan, 2018; Zheng et al., 2020). RCC is a strong material with unique properties that can preserve the stability of heavy-duty and mass concreting operations in structures and infrastructures. In general, RCC is a zeroslump concrete in its fresh state (ACl, 2011; Rao et al., 2016a, 2016b), handled by vibrating drums and rollers (Chhorn et al., 2018). It has the same components of conventional concrete (CC) (Courard et al., 2010), and its importance comes from the ability to provide a similar strength as CC (Harrington et al., 2010; Kokubu et al., 1996) with good durability and low maintenance requirements (Mohammed, 2018) at a significantly reduced cost (Courard et al., 2010; Nagayama \& Jikan, 2003; Warren, 2013). Furthermore, RCC has a good reputation across the world to erect various types of infrastructures, including pavements and hydraulic structures (Atiş, 2005; Chi \& Huang, 2014; C. Wang et al., 2018a). Currently, the literature is indeed lack of a detailed review that highlights the findings of these studies. This paper is intended to shortly review and summarize the remarks of recent investigations on the performance of RCC dams. As a part of this study, several aspects of RCC dams such as thermal and seismic behavior will be discussed, and the missing points in the literature will be underlined. This review is expected to help researchers in the field of civil engineering by presenting useful information about RCC dams.

\section{Roller Compacted Concrete in Brief}

The American Concrete Institute (ACl) defines RCC in ACl 116 as "concrete compacted by roller compaction; concrete that, in its unhardened state, will support a roller while being compacted" (ACl, 1985). Furthermore, RCC can be described as concrete that requires pavers for placement and rollers for compaction with the formation of many horizontal construction joints (Chen \& Liu, 2019; Q. Wang et al., 2018c; Zhou et al., 2016).

\subsection{History}

RCC was firstly used as a construction material for pavements in Sweden 1930s, Figure 1. Thereafter, its applications intensively started in the early 1960 s with the industry orientation towards eco-friendly and cost-effectively materials to face the challenges and meet objectives of the expanded and diverse applications in the construction sector. Since the early 1980s, RCC was accepted as a suitable material for dams, and by the end of 2012, over 550 RCC dams were erected worldwide (Ashtankar \& Chore, 2014). Currently, several researches are investigating the use of recycled aggregates in RCC towards sustainable concrete.

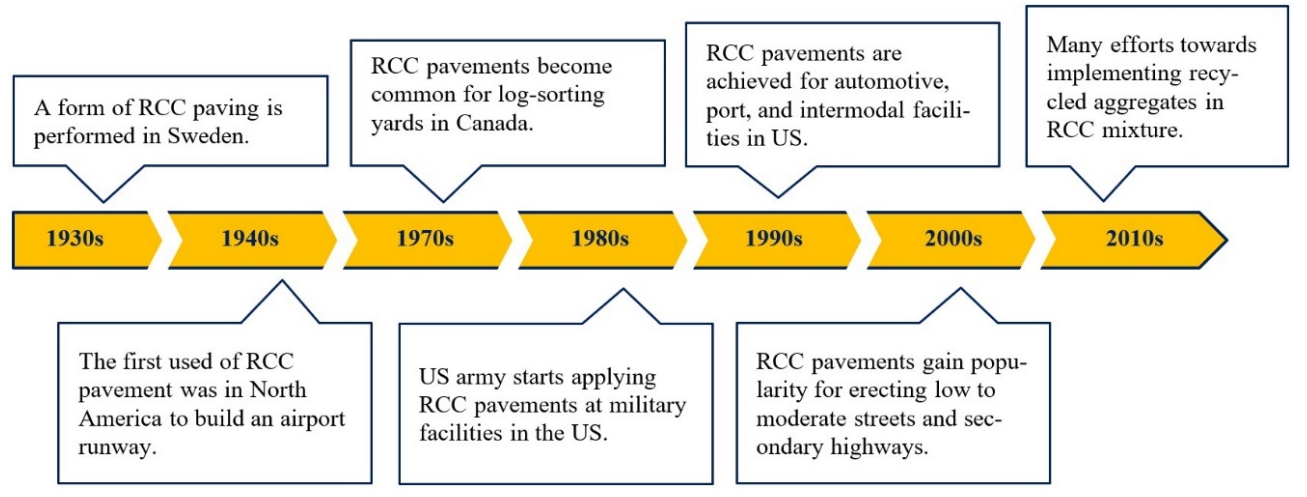

Figure 1: The history of RCC (mainly collected from (Harrington et al., 2010))

\subsection{Constituents}

RCC is composed of aggregates (both fine and coarse), water, cementitious materials (including cement, fly ash and etc.), which are the same constituents used in CC. Despite the fact that the materials used in RCC are the same as in CC, the mix proportion is totally different (Tun et al., 2016) in the sense of RCC contains a higher fine aggregate amount in comparison to CC resulting in a stiffer material that requires more energy to the place and compact (Harrington et al., 
2010). The relatively small amount of water added to the RCC mixture makes it suitable to be placed and compacted in a similar way to the asphalt pavement (Saleh et al., 2017). Even though cement is the main cementitious material in RCC, pozzolan, such as fly ash, can partially replace cement to decrease cost, heat generation and/or CO2 emission (ACl, 2011). Furthermore, various chemical admixtures can be added to achieve the targeted characteristics of concrete, where the most common ones are water-reducing and air-entraining admixtures (Al Baghdady \& Khan, 2018).

\subsection{Mix Proportioning of Roller Compacted Concrete}

In general, RCC are divided into two main categories which are the lean paste RCC (cement content $>99 \mathrm{~kg} / \mathrm{m} 3$ ) and the high paste RCC (cement content $<180 \mathrm{~kg} / \mathrm{m3}$ ) (Liapichev, 2003). As a result, the proportioning methods of RCC can be classified into soil and concrete approaches, which arise from the fact that RCC behaves in the beginning as soil and then develops as a true concrete (Choi \& Groom, 2001). The soil approach is useful for lean paste RCC in which the mix is considered as an embankment where its properties are evaluated based on the moisture-density relationship, which represents the cement content and moisture of the mixture by determining the maximum dry density under compaction effort using the standard proctor test (Armanpour \& Tajdini, 2016). On the other hand, the concrete approach is used for both CC and RRC in which RCC mixture is designed to achieve the required consistency with controlling water/cement ratio, aggregate/fine ratio and cement/pozzolan ratio to decrease the voids in the mixture by increasing the total aggregate content and filling the fine aggregate voids with cement paste. Therefore, the basic proportioning approach is similar in both normal and RCC concretes (Army, 1987) with significantly lower water content and higher fly ash /sand ratio in RCC to limit the occurrence segregation (Bauchkar \& Chore, 2012).

\subsection{Properties of Roller Compacted Concrete}

The density of RCC ranges between $1 \%$ and $3 \%$ higher than the CC. (Army, 2000), due to the low water amount and insufficient air entrained in the mix resulting in more dense material (Al Baghdady \& Khan, 2018). On the other hand, the compressive strength values are similar to those in CC and mainly affected by water/cement ratio, compaction effort and content, and type of aggregate. The tensile strength of RCC is an important parameter for the seismic analysis of RCC dams and can be controlled by the aggregate bond (Al Baghdady \& Khan, 2018; Army, 2006). Therefore, this parameter must be tested in the lift joints where the weakest zones in RCC are located. In fact, the tensile strength testing methodologies can be divided into direct and indirect approaches (Al Houri et al., 2020). The direct method is used to measure the strength between the lifts while the indirect splitting one is used when the tensile strength of the unjointed RCC is desired. Besides that, strength properties, the shear strength of RCC is used to define the critical measures for the design in the lift joints (Army, 2000). In dam's construction, the required modulus of elasticity needs to be low to reduce the possibility of development of cracks by controlling the stress and increasing the deformation (Al Baghdady \& Khan, 2018), whereas, the Poisson's ratio in RCC is comparable to that in CC and ranging from 0.17 to 0.22 (ACl, 2011 ). In general, excessive seepage is often undesirable due to its negative impact on the structural stability, durability, and economic value associated with lost water and the adverse appearance of water seepage on the downstream face. Thus, controlling seepage is indeed vital for the long-term efficiency of dams; this can be done by taking precautions for the factors affecting the permeability of RCC represented by the method of placement, proportioning of the mixture, and degree of the compaction. (Army, 2000). As a matter of fact, concrete mixtures with high modulus of elasticity and high strength have relatively low creep, while those with low strength and modulus of elasticity have larger creep values. In general, it is desirable for the concrete mixes in RCC dams to have high creep properties in order to relieve stress and strain buildup due to foundation restraint and thermal and exterior loadings (Al Baghdady \& Khan, 2018). On the other hand, in dam construction, all types of shrinkage must be controlled in all types of dams to reduce the uncontrolled cracking associated with the volume changes. Since drying shrinkage is related to the amount of water and properties of aggregates, its values in RCC is comparable or less than the CC (Army, 2000) whereas, autogenous shrinkage is related to material properties, exhibits higher values with an increase in the concrete strength. However, as the hydration starts to occur, the temperature of concrete starts to exceed the ambient temperature, but later as is starts to cool down to reach the ambient temperature, the contraction takes place resulting in the thermal shrinkage (Abdulrazeg et al., 2010). The thermal properties of RCC mixes are highly affected by the type and content of aggregate and cementitious materials in which mixtures with low cementitious materials shows low rise in temperature (Dunstan, 2003). Thus, testing the properties of RCC using the full RCC mixture is recommended ( $\mathrm{ACl}, 2011)$. Generally, the adiabatic temperature increase in mass concrete is normally tested for 28 days, where most mixes produce little temperature rise beyond that time. On the other hand, a high-pozzolan RCC mixture may have a considerable delay in early-age temperature rise in which it significantly increases beyond 28 days. Therefore, RCC mixtures with over $30 \%$ pozzolan should be tested for adiabatic temperature rise and other properties to an age of at least 56 days $(\mathrm{ACl}, 2011)$. 


\subsection{RCC as a Mass Concrete Material}

$\mathrm{ACl}$ CT-18 (ACl, 2013) defines mass concrete as "Any volume of structural concrete in which a combination of dimensions of the member being cast, the boundary conditions, the characteristics of the concrete mixture, and the ambient conditions can lead to undesirable thermal stresses, cracking, deleterious chemical reactions, or reduction in the long-term strength as a result of elevated concrete temperature due to heat from hydration." This material is designed to reach adequate durability demands and resist the thermal effects in an economical way with minor concerns about its strength capacity $(\mathrm{ACl}, 2005)$. There are some variations between the conventional mass concrete and the RCC, but the essential difference can be noticed in the consistency of the mixture and its compaction technique in which internal one is applied to CC by immersion-type vibrators method and an external one for RCC through spreading equipment and vibrating rollers (Bauchkar \& Chore, 2012). Nowadays, RCC is deemed as the most practical solution for designing and constructing major hydropower and water resource projects across the globe due to the considerable cost difference along with the construction and casting speed compared to CC (ACl, 1995; Rooholamini et al., 2018; L. Wang et al., 2018b; Warren, 2012; Yang \& Shi, 2009).

\subsection{Advantages and Disadvantages}

For many years RCC has been used in constructing dams, lumber storage yards, heavy haul roads, loading docks, intermodal port facilities, and parking lots (Aghaeipour \& Madhkhan, 2019). The main benefits of this type of concrete, when used in dams, comes from its reduced cost that ranges from $25 \%$ to $50 \%$ compared to the CC ones in addition to its rapid construction process that helps in saving 1 to 2 years less than the CC dams (Zarrin et al., 2016). On the other hand, RCC dams are built up in layers by applying large quantities of concrete to form a monolithic mass-concrete structure (Husein Malkawi \& Qiu, 2003). However, this construction process results in increased risks for bedding slip and seepage problems (Liu et al., 2018; Rongmei \& Wei, 2007; Su et al., 2018; Yahui \& Guowei, 1995).

\section{Roller Compacted Concrete Dams}

A dam in civil engineering discipline refers to an artificial barrier together with its related works that are built to impound, divert water, or liquid material. This structure might compose of timber, rock, CC, RCC, earth, steel, or a combination of these materials (DEQ, 2007).

\subsection{Advantages and Disadvantages}

Two types of RCC dams are widely applied: (1) the gravity dam, Figure 2-a, which is commonly known as the oldest structure that can withstand the external loads through its self-weight only (PCA, 2003; Punmia et al., 2009), (2) the arch dam, Figure 2-b, is a curvy, thinner dam as compared to the gravity one and can transfer high water loads to the abutments in the horizontal direction using the arch action (Al Baghdady \& Khan, 2018; Punmia et al., 2009). A comparison between the pros and cons of these dams is presented in Table 1.

Table 1 Advantages and disadvantages of gravity and arch dams (collected mainly from (Punmia et al., 2009))

\begin{tabular}{|c|c|c|}
\hline Type of dam & Advantages & Disadvantages \\
\hline \multirow[t]{6}{*}{ Gravity dam } & - Stronger and more stable than the other types. & - Not useful for weak and shallow foundations. \\
\hline & - It can be used for overflow spillway crest. & · Higher initial cost. \\
\hline & - It can be built at any height. & - Needs skilled and experienced workers for implementation. \\
\hline & - Suitable for places with very heavy and strong rain. & $\begin{array}{l}\text { - Difficult to increase the height later unless this was considered in the initial } \\
\text { design. }\end{array}$ \\
\hline & - Needs less maintenance schedules. & \\
\hline & . Cost-effective for long-term usage. & \\
\hline \multirow[t]{5}{*}{ Arch dam } & $\begin{array}{l}\text { - It provides enhanced performance against seismic induced forces } \\
\text { and tolerates the de-sign loads with less concrete volume than } \\
\text { gravity dam (Pedro, 2014). }\end{array}$ & $\begin{array}{l}\text { - It costs more and needs special attention to the treatment of the foundation } \\
\qquad(\text { Pedro, 2014). }\end{array}$ \\
\hline & - The length is small in comparison to height. & $\begin{array}{l}\text { - It requires very skilled and experienced workers for implementation compared } \\
\text { with the gravity dam. }\end{array}$ \\
\hline & $\begin{array}{l}\text { - The cross-section is thinner, and thus less concrete volume is } \\
\text { needed. }\end{array}$ & - Slow construction speed and longer period. \\
\hline & - Less base width and thus small effect of uplift pressures. & - Needs solid abutments to withstand arch thrust. \\
\hline & - It can be built up of a moderate foundation. & \\
\hline
\end{tabular}




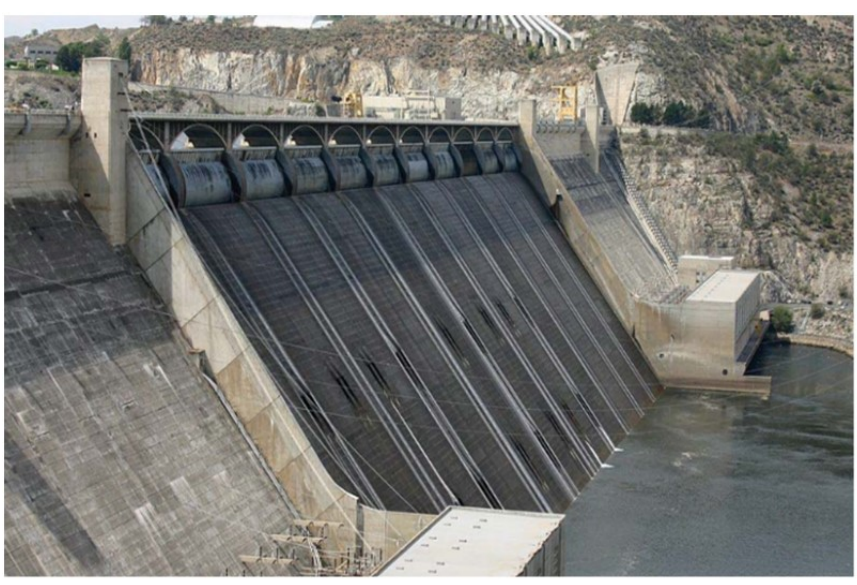

(a)

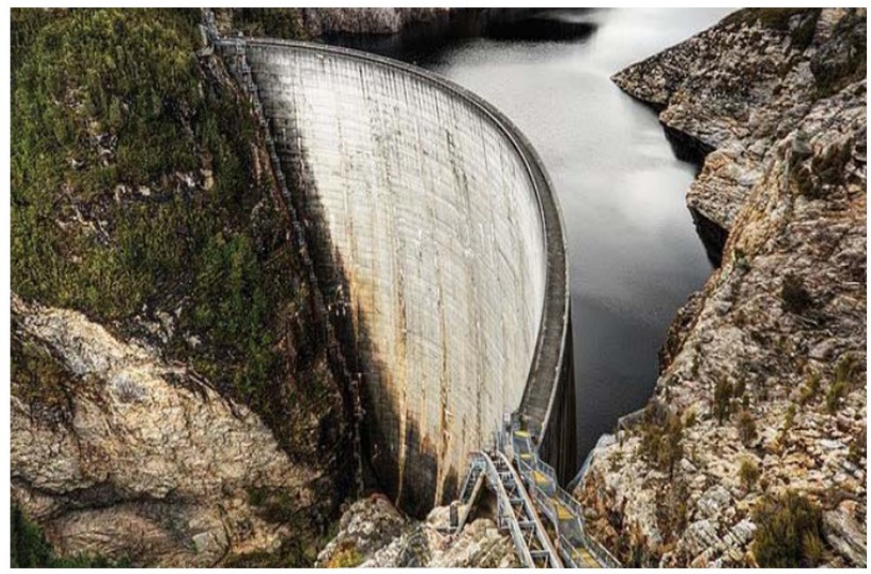

(b)

Figure 2: (a) Grand Coulee dam in Washington - USA, (b) Gordon Dam, Tasmania - Australia

\subsection{Advantages and Disadvantages}

Concrete dams are massively large structures that are designed taking into consideration the cost, time schedule, tightness of water, a semblance of the RCC dam and method of construction and maintenance to achieve the stability and fulfill the requirements of long-life spans and water tightness by sustaining the application of different loading and environmental conditions. The loadings selected for the stability analysis, an example of a gravity dam is shown in Figure 3 , which must represent the actual loads that are going to act on the concrete dam during its entire life span (Broberg \& Thorwid, 2015). In many cases, these loads are of such a nature that cannot exactly be determined. Thus, the designing engineer is then responsible for estimating their intensity, direction, and location-based on all available facts, judgment, and experience (FERC, 2002).

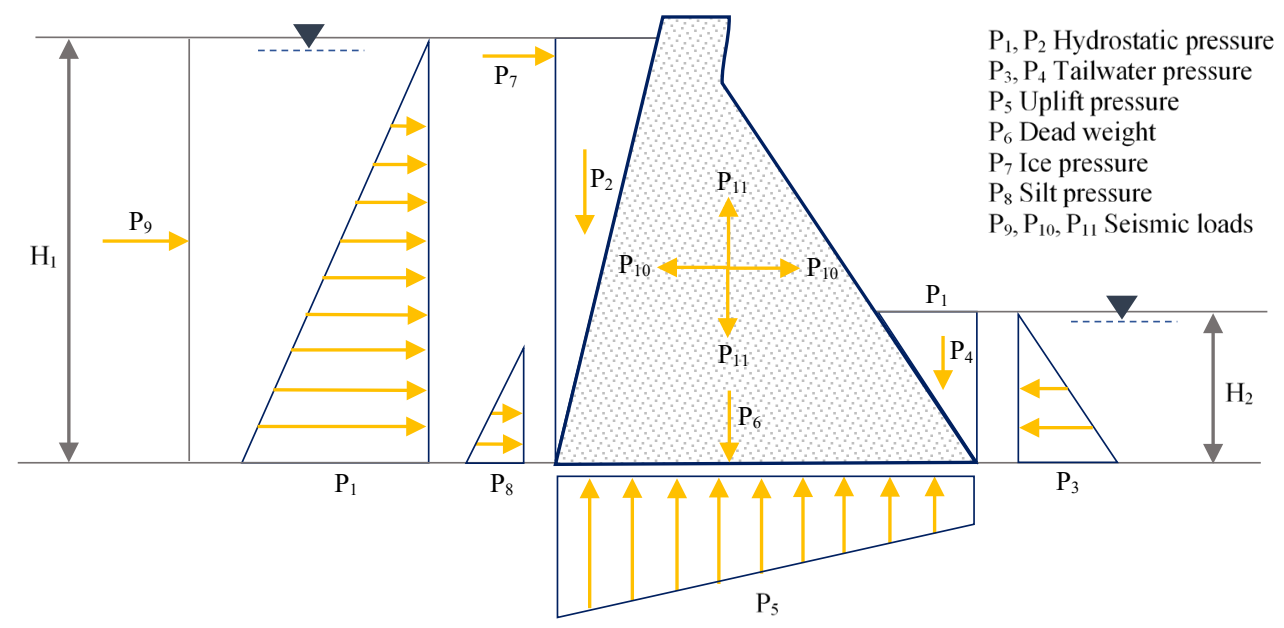

Figure 3: An example of the loads acting on a gravity dam (reproduced from (Broberg \& Thorwid, 2015))

In similar to CC dam, the RCC failure is considered as one of the most catastrophic events and defined as a collapse or movement of part of a dam or its foundation/ abutments so that this structure cannot retain water anymore (ICOLD, 1995). Therefore, this structure is designed to maintain safe behavior against sliding, overturning, and induced stresses. Sliding, Figure 4-a, can occur in dams due to the movement and friction between the horizontal planes of the dam or at the connections between the material used in the foundation and the dam and this can be prevented by ensuring the full transfer of all horizontal forces from the dam to the foundation. On the other hand, overturning, Figure 4-b, can occur at the connection between the foundation and the dam or in the foundation itself, which can be prevented by ensuring that the ratio of stabilizing moment to overturning moment is higher than the safety value against overturning action (Hansen \& Reinhardt, 1991). 


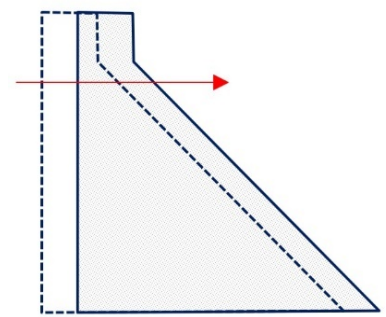

(a)

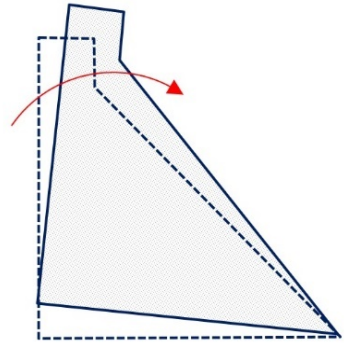

(b)

Figure 4: (a) Sliding failure, (b) overturning failure (reproduced from (Broberg \& Thorwid, 2015))

In construct, to CC dams, the RCC ones are constructed in many thin horizontal layers, which increase the risk for strength, stability, and seepage of the dam. Generally, the anti-sliding stability is ignored, as discussed by Sha et al. (Sha et al., 2016), in RCC gravity dams of $100 \mathrm{~m}$ in height, but for dams with $200 \mathrm{~m}$ high, this issue is very prominent and must be considered to prevent the failure mechanism composed of shear slipping along the layer surfaces and the foundation surface. Further attention must be taken obviously to prohibit a failure in the dam's cross-section that occurs when the stresses in the foundation or in the concrete surpass the allowable stresses.

\section{Finite Element Modeling and Analysis}

Nowadays, Finite Element (FE) modeling is widely accepted as a powerful tool for conducting a comprehensive study and evaluating the behavior of structural elements under different loading conditions (Habib et al., 2020; Lampropoulos \& Dritsos, 2011). In general, dams are simulated in 2D or 3D, Figure 5, and the observed variation between the analysis results of these two modeling methods in the case of seismic performance, Figure 6, is emerged from the change in the stiffness, fundamental periods and the geometrical effects, which increase the capacity of the stiffer model under earthquake excitations (Arici et al., 2014). The numerical findings in the thermal analysis have relied on various factors such as the time of the year, the ambient air temperature, RCC placement temperature, and heat of hydration of the cementitious materials (Husein Malkawi \& Qiu, 2003; Xia, 2017).

It is possible to simulate the effects of incremental construction stages in mass concrete structures using commercially available FE software packages with sufficient laboratory data (Husein Malkawi \& Qiu, 2003). Therefore, the FE method provides an effective way for estimating the seismic, Figure 7, and thermal, Figure 8, the behavior of RCC dams when appropriate boundary conditions are sufficient (Chen \& Liu, 2019; Gharibdoust et al., 2019; Jia et al., 2010). Kartal (Kartal, 2012) also mentioned that in order to carry out a seismic performance analysis of RCC dam both gravity loads and hydrostatic pressure should be taken into account before applying the earthquake shaking intensities, in addition, the material, geometrical and connection nonlinearities must be defined be considered to predict a reliable dam behavior.

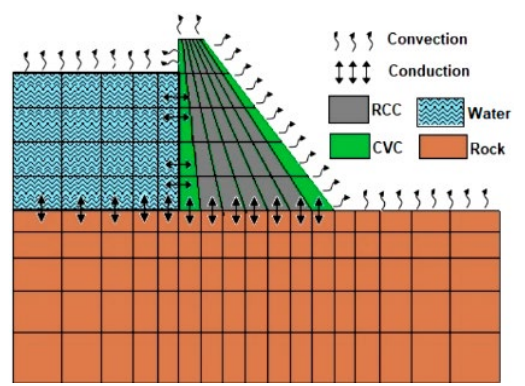

(a)

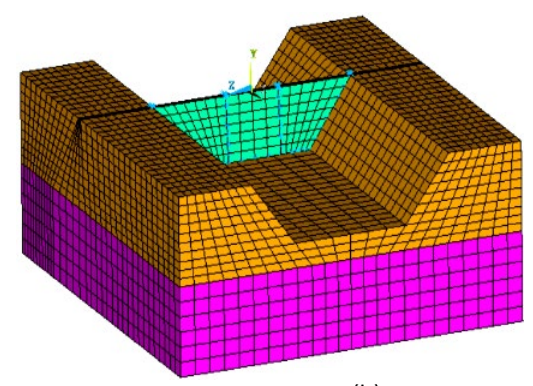

(b)

Figure 5: ((a) 2D (Bayagoob \& Bamaga, 2019), (b) 3D (Kartal, 2012) simulation of RCC dam and its foundation

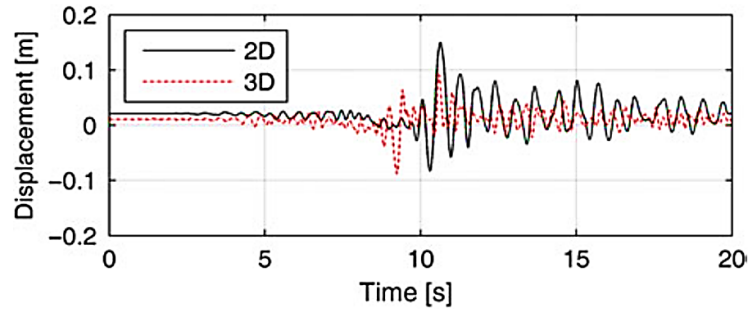

Figure 6: Crest displacement under earthquake excitation for 2D and 3D models (Arici et al., 2014) 


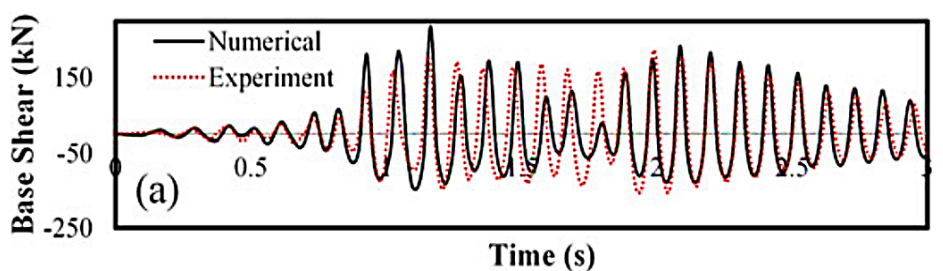

Figure 7: A comparison between the experimental and numerical base shear-induced in RCC dam under dynamic loading (Gharibdoust et al., 2019)

The accuracy of FE analysis is mainly based on the defined geometrical and material properties and laws used in developing the governing equations (Perumal \& Mon, 2011) then the modeling phase should be addressed carefully. Jia et al. (Jia et al., 2010) provided a process for thermal analysis of RCC dam in FE environment, as indicated in Figure 9. Typically, the FE modeling of dams is similar to any other structure and goes through several stages, which consist of definition, calculation, and results interpretation.

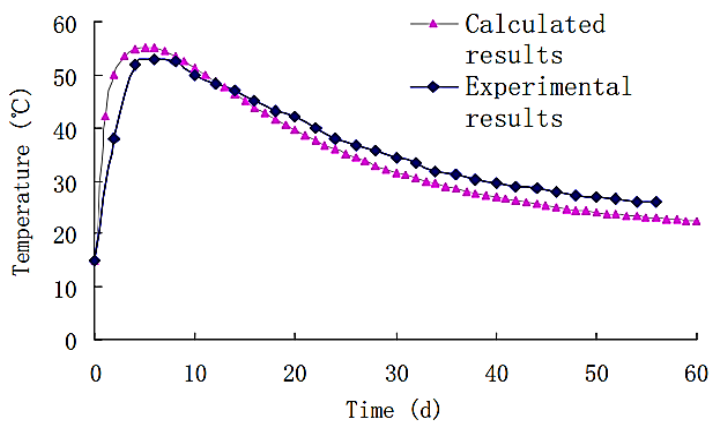

Figure 8: A comparison between the experimental and numerical results of temperature (Jia et al., 2010)

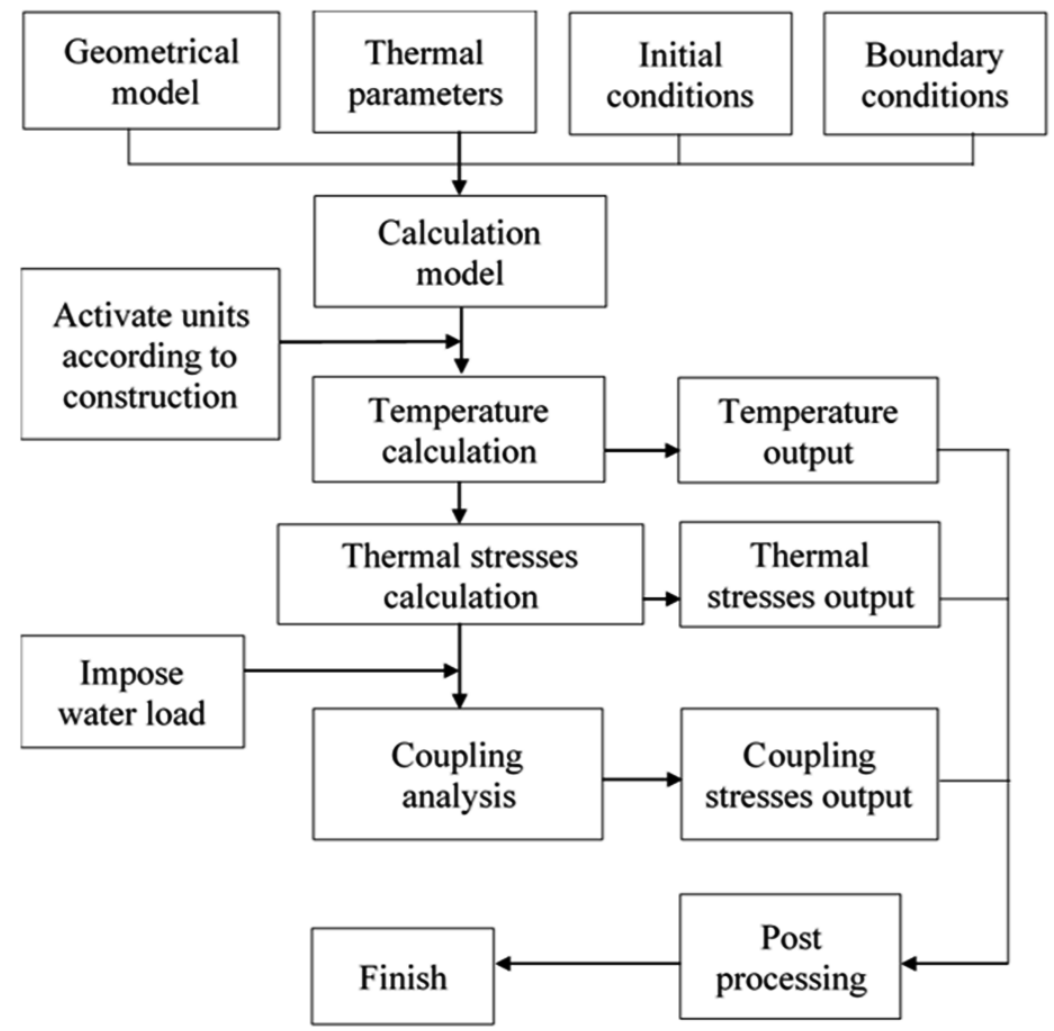

Figure 9: Flowchart of RCC dam thermal analysis using Ansys APDL (Jia et al., 2010)

There are different tools for performing a FE analysis, such as a commercially available software package like Abaqus (Abaqus, 2010), Ansys (Ansys, 2012), Diana (Wang \& Chopra, 2008), and SAP 2000 (Wilson \& Habibullah, 1989) or a coded 
program in FORTRAN or another language. Table 2 shows a summary of the used software in the analysis of previous studies.

Table 2 FE modeling of RCC dams

\begin{tabular}{|c|c|c|c|}
\hline Author/s & Program used & Type of Analysis & Modeling Strategy \\
\hline $\begin{array}{l}\text { Bayagoob \& Bamaga } \\
\text { (2019) }\end{array}$ & $\begin{array}{l}\text { A coded program (Bayagoob, } \\
\text { 2008) }\end{array}$ & Thermal analysis & $\begin{array}{l}\text { The model composed of eight nodes isoparametric elements, } \\
1 \mathrm{~m} \text { thick RCC layer, two layers of CC at the upstream and } \\
\text { downstream faces, and rock foundation with a width and } \\
\text { depth similar to the height of the dam. The heat transfer } \\
\text { between the enclosed water and the upstream part of the } \\
\text { dam was simulated using the FE method. Furthermore, the FE } \\
\text { elements of water were incorporated as layers in an almost } \\
\text { identical way as the incorporation of RCC layers inconsistency } \\
\text { with filling a table of a reservoir. The crest, upstream and } \\
\text { downstream of the dam along with the crest of the reservoir } \\
\text { are open to air resulting in convection at these boundaries } \\
\text { due to heat exchange. Moreover, the conditions of these } \\
\text { boundaries are bound to change as the process of filling the } \\
\text { reservoir begins creating conductivity of heat between the } \\
\text { submerged upstream part, water in a reservoir, and crest of } \\
\text { rocky foundation. }\end{array}$ \\
\hline Ghaedi et al. (2016) & Abaqus & Nonlinear dynamic analysis. & $\begin{array}{l}\text { In this study, the dam body was simulated using four nodes } \\
\text { bilinear plane stress quadrilateral finite elements with } \\
\text { reduced integration and hourglass, whereas the reservoir } \\
\text { water was modeled using the four nodes linear 2D acoustic } \\
\text { quadrilateral finite elements. In addition, the dam body was } \\
\text { meshed by simulating the construction phases. RCC concrete } \\
\text { was implied as a composite material that experiences major } \\
\text { strain-softening (J. G. M., 1997). However, this definition of } \\
\text { concrete may result in mesh sensitivity and to overcome its } \\
\text { concrete damaged plasticity model was used. Cracking in } \\
\text { tension and crushing in compression are the main } \\
\text { mechanisms of failure in the body of the dam. The brittle } \\
\text { behavior of concrete vanishes while the limited pressure is } \\
\text { sufficient to prevent crack propagation. Therefore, failure is } \\
\text { caused by the stabilization and collapse of the concrete } \\
\text { microporous microstructure resulting in a macroscopic } \\
\text { response that leads to resemble the ductile material with } \\
\text { work hardening. }\end{array}$ \\
\hline \multirow[t]{5}{*}{$\begin{array}{l}\text { Mughieda et al. } \\
\qquad(2018)\end{array}$} & \multirow[t]{5}{*}{ SAP 2000} & \multirow[t]{5}{*}{$\begin{array}{l}\text { Dynamic stability against } \\
\text { sliding. }\end{array}$} & $\begin{array}{l}\text { The simulation consisted of using four nodes isoperimetric } \\
\text { plain strain having } 2 \text { degrees of freedom in each node and } \\
\text { three nodes constant strain triangular having } 2 \text { degrees of } \\
\text { freedom in each node. The FE meshing of dam cross-section } \\
\text { was conducted using a coded tool in Fortran. Overall, the } \\
\text { following assumptions were taken: }\end{array}$ \\
\hline & & & . Plain strain linear elastic behavior. \\
\hline & & & $\begin{array}{l}\text { - Simplified soil-structure interaction entailing massless elastic } \\
\text { foundation. }\end{array}$ \\
\hline & & & - Uniform and homogenous foundation. \\
\hline & & & $\begin{array}{l}\text { Finally, foundation boundaries were fixed in restricted from } \\
\text { translation and rotation, and all out of a plane degree of } \\
\text { freedom were restrained. }\end{array}$ \\
\hline $\begin{array}{l}\text { Gharibdoust et al. } \\
\text { (2019) }\end{array}$ & ANSYS & $\begin{array}{l}\text { Pushover and time history } \\
\text { analysis }\end{array}$ & $\begin{array}{l}\text { Eight nodes brick elements were used to model the cracking } \\
\text { and crushing of concrete based on the 3D failure surface } \\
\text { suggested by Willam and Warnke (Willam \& Warnke, 1975). } \\
\text { The dam was simulated in 3D FE environment to overcome } \\
\text { the limitation of the adopted failure model in considering the } \\
\text { 2D stress conditions to predict the crack and crush states of } \\
\text { concrete. }\end{array}$ \\
\hline
\end{tabular}




\section{Previous Works on RCC Dams}

In fact, the majority of previous works in this field were numerical investigations. Thus, this section provides a summary of the objective of previous numerical studies available in literature as a table format, Table 3 , and Table 4.

Table 3 FE modeling of RCC dams

\begin{tabular}{|c|c|c|c|}
\hline Author/s & Dimensions & Aim of the study & Remarks \\
\hline $\begin{array}{l}\text { Bayagoob \& Bamaga } \\
\qquad(2019)\end{array}$ & $2 \mathrm{D}$ & $\begin{array}{l}\text { Evaluating the construction suitability of } \\
\text { RCC dams in arid regions, taking into } \\
\text { account the most influential parameters } \\
\text { such as temperature. }\end{array}$ & $\begin{array}{l}\text { Using suitable RCC placement schedule can enable } \\
\text { the application of RCC dams in arid regions. }\end{array}$ \\
\hline Ghaedi et al. (2016) & $2 \mathrm{D}$ & $\begin{array}{l}\text { Conducting a nonlinear dynamic analysis } \\
\text { on RCC dams. }\end{array}$ & $\begin{array}{l}\text { Circular gallery shape showed the best results in } \\
\text { crack propagation analysis and displacement } \\
\text { response compared to square and octagon galleries. }\end{array}$ \\
\hline $\begin{array}{l}\text { Mughieda et al. } \\
\qquad(2018)\end{array}$ & $2 \mathrm{D}$ & $\begin{array}{l}\text { Studying the stability of RCC dam against } \\
\text { sliding. }\end{array}$ & $\begin{array}{l}\text { The rock is adjacent to the toe of the upstream } \\
\text { slope experience the highest tension in the dam. }\end{array}$ \\
\hline Heirany (2017) & $2 \mathrm{D}$ & $\begin{array}{l}\text { Investigating and modeling the dynamic } \\
\text { analysis of RCC dam, taking into } \\
\text { consideration the effect of foundation. }\end{array}$ & $\begin{array}{l}\text { The effect of mass foundation on the seismic } \\
\text { behavior showed a reduction in tensions and } \\
\text { displacements, whereas massless foundation } \\
\text { showed an increase in tensions and displacements. }\end{array}$ \\
\hline $\begin{array}{l}\text { Khanzaei et al. } \\
\text { (2015) }\end{array}$ & $2 \mathrm{D}$ & $\begin{array}{l}\text { Studying the thermal and structural } \\
\text { response of RCC dams within the service } \\
\text { life. }\end{array}$ & $\begin{array}{l}\text { Thermal stresses in the dam increase as the } \\
\text { operation period of the dam increase. }\end{array}$ \\
\hline Jiang et al. (2013) & $2 \mathrm{D}$ & $\begin{array}{l}\text { Estimating the distribution of temperature } \\
\text { in different locations of RCC dams during } \\
\text { construction. }\end{array}$ & $\begin{array}{c}\text { Solar radiation has a high effect on temperature } \\
\text { history in central and surface regions nodes and less } \\
\text { impact on their temperature difference compared } \\
\text { to pouring temperature, which has significant } \\
\text { influence. }\end{array}$ \\
\hline $\begin{array}{l}\text { Noorzaei et al. } \\
\text { (2006) }\end{array}$ & $2 \mathrm{D}$ & $\begin{array}{l}\text { Verifying the developed 2D FE model for } \\
\text { the thermal-structural behavior of RCC } \\
\text { dams. }\end{array}$ & $\begin{array}{l}\text { Determination of RCC real thermal response is } \\
\text { related to the material properties, recorded air } \\
\text { temperatures, and real RCC placement schedule. }\end{array}$ \\
\hline Arici et al. (2014) & $2 \mathrm{D}$ and $3 \mathrm{D}$ & $\begin{array}{l}\text { Comparing the nonlinear dynamic analysis } \\
\text { of RCC dams of 2D and 3D FE models. }\end{array}$ & $\begin{array}{l}\text { Usage of high strength grout-enriched concrete at } \\
\text { the upstream and downstream surfaces of the dam } \\
\text { has been observed to minimize the cracks at the } \\
\text { base of the dam. }\end{array}$ \\
\hline Shamsai et al. (2009) & $2 \mathrm{D}$ and $3 \mathrm{D}$ & $\begin{array}{l}\text { Studying the thermo-mechanical behavior } \\
\text { of RCC dam. }\end{array}$ & $\begin{array}{l}\text { Tension stress is greatly affected by the starting } \\
\text { season and schedule of structure. The maximum } \\
\text { temperature region exists at the first RCC layer. }\end{array}$ \\
\hline $\begin{array}{l}\text { Husein Malkawi et al. } \\
\qquad(2004)\end{array}$ & $2 D$ and $3 D$ & $\begin{array}{l}\text { Studying the thermal behavior of RCC } \\
\text { gravity dam. }\end{array}$ & $\begin{array}{c}\text { 2D and 3D analysis yield similar thermal values with } \\
\text { minor differences between both types. }\end{array}$ \\
\hline $\begin{array}{l}\text { Husein Malkawi \& } \\
\text { Qiu (2003) }\end{array}$ & $2 \mathrm{D}$ and $3 \mathrm{D}$ & $\begin{array}{l}\text { Modeling thermal- structural and } \\
\text { temperature control of RCC gravity dam. }\end{array}$ & $\begin{array}{c}\text { For large RCC dams, detailed thermal stress analysis } \\
\text { is required to reduce and control the formation of } \\
\text { thermal cracks. }\end{array}$ \\
\hline
\end{tabular}

Table 4 Summary of previous 3D FE studies on RCC dams

\begin{tabular}{|c|c|c|c|}
\hline Author/s & Dimensions & Aim of the study & Remarks \\
\hline Kartal (2012) & $3 D$ & $\begin{array}{l}\text { Investigating the seismic response of RCC } \\
\text { dams. }\end{array}$ & $\begin{array}{l}\text { Nonlinear material analysis exhibited safer principle } \\
\text { stresses in comparison to linear analysis. }\end{array}$ \\
\hline $\begin{array}{l}\text { Gharibdoust et al. } \\
\qquad \text { (2019) }\end{array}$ & $3 D$ & $\begin{array}{l}\text { Investigating the seismic response of RCC } \\
\text { dams. }\end{array}$ & $\begin{array}{l}\text { Estimation of the friction coefficient is a challenging } \\
\text { aspect in the design and evaluation of the dams since it } \\
\text { allows for the determination of the predicted mode of } \\
\text { failure. }\end{array}$ \\
\hline Zhang et al. (2019b) & $3 D$ & $\begin{array}{l}\text { Simulating the construction process of an RCC } \\
\text { dam and calculate its temperature field. }\end{array}$ & $\begin{array}{c}\text { During cold seasons, natural waterhousing watering is } \\
\text { used for pouring, whereas in hot seasons, control casting } \\
\text { temperature approach and water-cooling measures are } \\
\text { used. }\end{array}$ \\
\hline
\end{tabular}


Table 4 Continued...

\begin{tabular}{|c|c|c|c|}
\hline Author/s & Dimensions & Aim of the study & Remarks \\
\hline Zhang et al. (2019c) & $3 D$ & $\begin{array}{l}\text { Simulating the axial tensile test piece of RCC } \\
\text { dam. }\end{array}$ & $\begin{array}{c}\text { During cold seasons, natural waterhousing watering is } \\
\text { used for pouring, whereas in hot seasons, control casting } \\
\text { temperature approach and water-cooling measures are } \\
\text { used. }\end{array}$ \\
\hline Huang \& Wan (2018) & $3 D$ & $\begin{array}{l}\text { Introducing an approach for measuring the } \\
\text { viscoelastic deformation monitoring index of } \\
\text { RCC gravity dam. }\end{array}$ & $\begin{array}{l}\text { The orthogonal test method exhibited accurate results by } \\
\text { means of deformation monitoring index since it takes } \\
\text { into account the random parameters. }\end{array}$ \\
\hline Xia (2017) & $3 D$ & $\begin{array}{l}\text { Simulating the analysis of temperature } \\
\text { control of RCC arch dam. }\end{array}$ & $\begin{array}{l}\text { Controlling and reducing the formation of thermal } \\
\text { cracking can be achieved through detailed thermal stress } \\
\text { analysis. }\end{array}$ \\
\hline Zhou et al. (2016) & $3 D$ & $\begin{array}{l}\text { Introducing an approach for finding the } \\
\text { optimum temperature monitor scheme of } \\
\text { RCC dams using FE method and sensitivity } \\
\text { analysis approach. }\end{array}$ & $\begin{array}{l}\text { The maximum temperature and tensile stress in the dam } \\
\text { are highly affected by placement temperature (cannot } \\
\text { exceed } 15^{\circ} \mathrm{C} \text { ). }\end{array}$ \\
\hline Fang et al. (2017) & $3 D$ & $\begin{array}{l}\text { Suggesting a new approach for quantifying } \\
\text { the breach size for prognosticating the failure } \\
\text { of arch RCC dams. }\end{array}$ & $\begin{array}{l}\text { Estimating the failure likelihood of the dam by means of } \\
\text { determining the breach size as a new structural reliability } \\
\text { method. }\end{array}$ \\
\hline $\begin{array}{l}\text { Kuzmanović et al. } \\
\qquad(2015)\end{array}$ & $3 D$ & $\begin{array}{l}\text { Studying the behavior of thermal -stress state } \\
\text { of RCC gravity dams. }\end{array}$ & $\begin{array}{l}\text { 3D modeling can yield accurate thermal stress estimation } \\
\text { and transversal joint distance calculation of RCC gravity } \\
\text { dam. }\end{array}$ \\
\hline Li et al. (2015) & $3 D$ & $\begin{array}{l}\text { Investigating and analyzing the stress field } \\
\text { and seepage field of RCC gravity dams. }\end{array}$ & $\begin{array}{l}\text { Impervious layer in the three graded RCC exhibited poor } \\
\text { seepage resistance, unlike two graded RCC layers which } \\
\text { can enhance the seepage resistance performance despite } \\
\text { potential seepage channel development. }\end{array}$ \\
\hline $\begin{array}{l}\text { Abdulrazeg et al. } \\
\qquad(2014)\end{array}$ & $3 \mathrm{D}$ & $\begin{array}{l}\text { Developing a three-dimensional finite } \\
\text { element code for the thermal and structural } \\
\text { analysis of RCC arch dam. }\end{array}$ & $\begin{array}{l}\text { High tension stress is concentrated at the lower part and } \\
\text { abutment boundaries of the dam. }\end{array}$ \\
\hline $\begin{array}{l}\text { Tschuchnigg \& } \\
\text { Schweiger (2014) }\end{array}$ & $3 D$ & $\begin{array}{l}\text { Outlining the results of RCC dams in terms of } \\
\text { the performance of its deep foundation. }\end{array}$ & $\begin{array}{l}\text { A critical decrease of deep foundation elements can } \\
\text { result in a similar settlement behavior of RCC dam. }\end{array}$ \\
\hline $\begin{array}{l}\text { Cheng and Zhang } \\
\text { (2012) }\end{array}$ & $3 D$ & $\begin{array}{l}\text { Evaluating the ultimate anti-seismic capacity } \\
\text { of high arch dam. }\end{array}$ & $\begin{array}{l}\text { Under earthquake, the weakest parts in the arch dam to } \\
\text { form cracks are the arch end, middle and upper parts of } \\
\text { the arch crown. }\end{array}$ \\
\hline Gu et al. (2013) & $3 \mathrm{D}$ & $\begin{array}{l}\text { Establishing a fluid-solid coupling model of } \\
\text { RCC dams using endochronic damage factor. }\end{array}$ & $\begin{array}{l}\text { Using endochronic theory and damage mechanics, the } \\
\text { constitutive model of endochronic damage is derived } \\
\text { that is capable of showing the real behavior of RCC } \\
\text { compared to the elastic-plastic yield surface concept. }\end{array}$ \\
\hline Kartal (2012) & $3 D$ & $\begin{array}{l}\text { Investigating the seismic response of RCC } \\
\text { dam including nonlinear geometry. }\end{array}$ & $\begin{array}{l}\text { Nonlinear material analysis generates safer principal } \\
\text { stresses with comparison to linear material analysis. }\end{array}$ \\
\hline Su et al. (2011) & $3 D$ & $\begin{array}{l}\text { Investigating the safety assessment } \\
\text { approaches and failure mechanism of RCC } \\
\text { dams. }\end{array}$ & $\begin{array}{l}\text { For the safety evaluation of high dams, the safety } \\
\text { coefficient approach gives accurate and reliable results } \\
\text { that meet the engineering requirements. }\end{array}$ \\
\hline Zhang et al. (2011) & $3 D$ & $\begin{array}{l}\text { Studying the effect of superficial insulation on } \\
\text { RCC dams in cold places. }\end{array}$ & $\begin{array}{l}\text { Insulation board can decrease the tension stress zone } \\
\text { and depth near the dam face along with preventing crack } \\
\text { development on upstream and downstream faces. }\end{array}$ \\
\hline Li et al. (2010) & $3 D$ & $\begin{array}{l}\text { Studying the effect of Concrete Mixed with } \\
\mathrm{MgO} \text { on the thermal stress of RCC dams. }\end{array}$ & $\begin{array}{c}\text { Mixing } \mathrm{MgO} \text { with concrete can result in simplification in } \\
\text { temperature control measures and a reduction in } \\
\text { thermal stress. }\end{array}$ \\
\hline Jia et al. (2010) & $3 D$ & $\begin{array}{l}\text { Analyzing the thermal stress field of RCC } \\
\text { dams during the process of construction. }\end{array}$ & $\begin{array}{l}\text { Tension stresses decrease as getting closer to the } \\
\text { upstream surface. }\end{array}$ \\
\hline Jaafar et al. (2007) & $3 \mathrm{D}$ & $\begin{array}{l}\text { Studying the thermal behavior of RCC dams } \\
\text { using FE method. }\end{array}$ & $\begin{array}{l}\text { Optimizing the temperature region locations can be done } \\
\text { by changing the placing schedule. }\end{array}$ \\
\hline Xie \& Chen (2005) & $3 \mathrm{D}$ & $\begin{array}{l}\text { Finding the type and thickness of the } \\
\text { impervious layer in RCC dam. }\end{array}$ & $\begin{array}{l}\text { The temperature distribution of the dam is significantly } \\
\text { influenced by the thickness of the impervious layer rather } \\
\text { than the type of material used. }\end{array}$ \\
\hline Chen et al. (2003) & $3 D$ & $\begin{array}{l}\text { Studying the influence of construction } \\
\text { designs on the temperature field of RCC dam. }\end{array}$ & $\begin{array}{l}\text { Using temperature control measures, } 20 \% \text { of the } \\
\text { maximum temperature in the dam can be minimized. }\end{array}$ \\
\hline
\end{tabular}


Table 4 Continued...

\begin{tabular}{cccc}
\hline Author/s & Dimensions & Aim of the study & Remarks \\
\hline Chen et al. (2001) & 3D & $\begin{array}{c}\text { Studying the thermal stress of RCC dam using } \\
\text { 3D FE model relocating mesh method. }\end{array}$ & $\begin{array}{c}\text { Minimizing the placement temperature of RCC can be } \\
\text { very effective in controlling the maximum temperature in } \\
\text { the dam. }\end{array}$ \\
Luna \& Wu (2000) & 3D & $\begin{array}{c}\text { Simulating the temperature and stress fields } \\
\text { during the construction of RCC dam. }\end{array}$ & $\begin{array}{c}\text { RCC dams can be constructed during cold seasons } \\
\text { without the need for additional temperature control } \\
\text { measures. }\end{array}$ \\
SD et al. (2011) & $\begin{array}{c}\text { Suggesting a model for studying the time- } \\
\text { dependent concrete degradation caused by } \\
\text { chemo-mechanical damage within the life of } \\
\text { an arch dam. }\end{array}$ & $\begin{array}{c}\text { Seismic safety of the dam is inversely proportional to } \\
\text { aging effects, where the aging of an arch dam can lead to } \\
\text { an increase in tensile cantilever stresses during an } \\
\text { earthquake and thus more damage to the structure. }\end{array}$ \\
\hline
\end{tabular}

\section{Stress Analysis}

Dam, as a complex structure, is constructed to resist all applied loads during its intended life such that arising from gravity or lateral loads or thermal changes (DEQ, 2007). In fact, FE analysis has a wide range of roles, yet one of the key targets of this method is to calculate the stress in each portion of the structure. Thus, by using the FE approach, the stress state at each construction stage of the dam can be computed (Xia, 2017). These stresses can then be used, as discussed by Noorzaei et al. (Noorzaei et al., 2006), to calculate an indicator, crack index I_cr, for the probability of damage occurring using the following formula:

$I_{c r}=\frac{f_{c t}(t)}{\sigma(t)} \geq 1.0$

where $f_{-} c t(t)$ and $\sigma(t)$ is the RCC tensile strength and tensile stresses, respectively, at the time t. The importance of this parameter is that it can give a good prediction to the crack occurrence over time and hence, evaluate the dam's safety against cracking (Noorzaei et al., 2006).

Basically, the most critical stresses in RCC dam are achieved by considering the thermal and seismic effects at the same time (Kartal, 2012). Noorzaei et al. (Noorzaei et al., 2006) performed a stress analysis at all construction stages and computed the crack index with regard to the instantaneous RCC tensile capacity. It was concluded that the downstream part is a likely cracking area in which there is high restraint coming from the nearby rock foundation and the reduced tensile stresses caused by the self-weight of the dam in comparison to the upstream side due to the sloping effect downstream. Furthermore, Khanzaei et al. (Khanzaei et al., 2015) observed that considerable tensile stresses are developed mainly in the upstream and downstream faces, which are mainly caused by the restraint against environmental thermal variations, and at the bottom part of the dam because of the external restraint imposed by the foundation rock. Abdulrazeg et al. (Abdulrazeg et al., 2014) elucidated that the compressive stress contours in arch dams, Figure 10, are located primarily in the downstream region and slowly decrease toward the boundaries, which is attributed to the arch action.

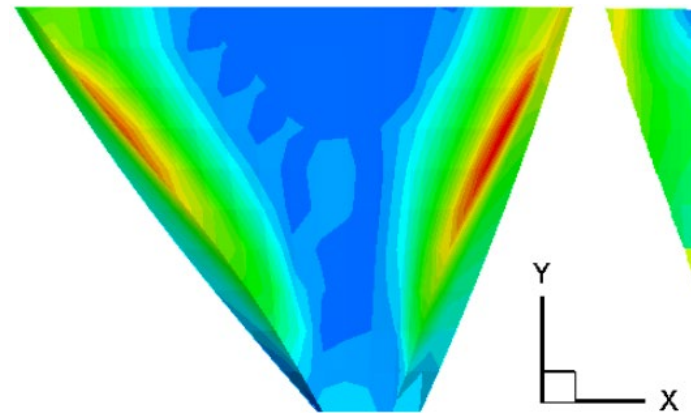

(a)

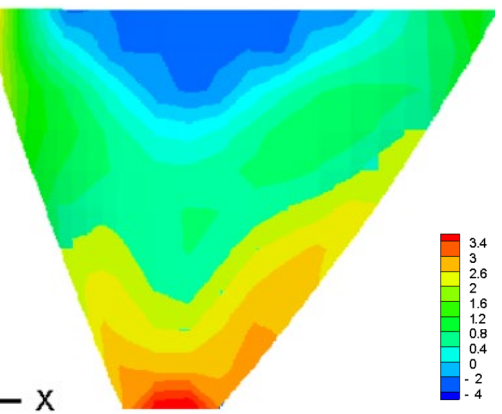

(b)

Figure 10: Principal stress distribution $\left(\sigma_{1}\right)$ in (a) downstream; (b) upstream face of an arch dam (Abdulrazeg et al., 2014)

\section{Thermal Analysis}

The stresses developed in RCC dams are highly related to its temperature field (Kuzmanovic et al., 2013). The generated heat in a dam depends primarily on the continuous hydration of cement. Normally, the RCC temperature gradually rises at the early setting time stage and rapidly increases in the following early few days (Chen \& Liu, 2019; Q. 
Wang et al., 2018c; Zhou et al., 2016), where the maximum temperature gradient occurs (Jia et al., 2010; Shamsai et al., 2009). Dam, in most cases, needs a long time to cool after erection as observed by Bayagoob and Bamaga (Bayagoob \& Bamaga, 2019), Figure 11, in which the dam body temperature stayed at a moderate level even after one year of construction. Moreover, the temperature of the outer node falls quickly to the annual average, while the internal ones may take several or over 10 years to stabilize the temperature field (Jia et al., 2010). Stress and temperature levels in the dam are highly influenced by heat conductivity rate and temperature field, which in turn is dependent and controlled by many factors, including starting date, construction plan, and air temperature (Chen et al., 2003; Zhang et al., 2011).

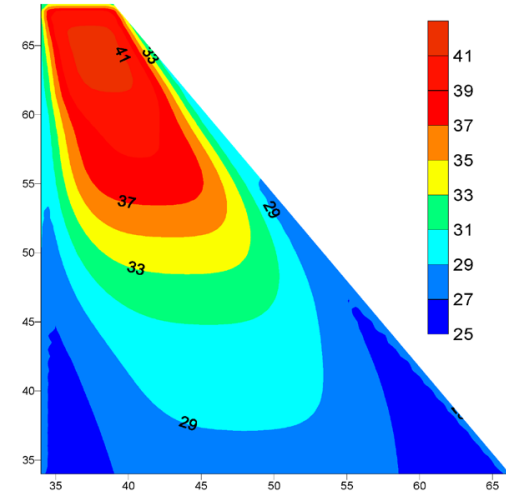

(a)

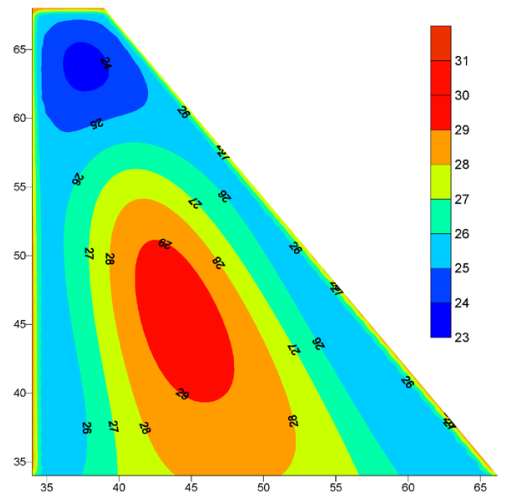

(b)

Figure 11: Temperature distributions: (a) immediately after constructing the dam; (b) one year later as observed (Bayagoob \& Bamaga, 2019)

As a matter of fact, the temperature during the placing of RCC plays a significant role in developing the temperature gradient (Abdulrazeg et al., 2014; Zhou et al., 2016). Kuzmanović et al. (Kuzmanović et al., 2015) stated that the best indicator of thermal behavior is stressed in the direction of dam axes. Zhou et al. (Zhou et al., 2016) found that a casting temperature of $20^{\circ} \mathrm{C}$ results in increasing the maximum tensile stress and temperature beyond the specified provision limits, while the optimum one at placement can be either $12{ }^{\circ} \mathrm{C}$ or $15^{\circ} \mathrm{C}$ for controlled stresses. Moreover, casting a dam in hot weather can cause high temperatures at the low body part due to the larger thickness at this portion leading to higher insulation requirements (Abdulrazeg et al., 2014). The temperature variation between central and surface nodes is attributed to the temperature at casting and should be monitored while constructing an RCC dam in hot weather, in addition, the nodes in central and surface zones are affected noticeably by solar radiation at later age of placement (Jiang et al., 2013).

Proper scheduling of concrete placement optimizes high-temperature regions and reduces the tension developed at the critical locations. Chen et al. (Chen et al., 2003) indicated that the highest temperature developed in the dam could be controlled by decreasing the casting temperature. Furthermore, thermal insulation can be used to reduce the tensile stresses zone, temperature gradient, and the difference between the internal and external temperatures, and to stop any possible crack formation on the surfaces of upstream and downstream (Zhang et al., 2011). Moreover, using a $10 \mathrm{~cm}$ insulation layer can keep the maximum tensile stress under the standard limitations (Zhou et al., 2016). The probability of crack, as preceding findings revealed, is affected by thermal insulation thickness (Zhou et al., 2016) and crack index (Noorzaei et al., 2006). Noorzaei et al. (Noorzaei et al., 2006) mentioned that the real thermal response of the RCC dam is based on the material properties, actual RCC placement plan, and the recorded ambient temperatures. On the other hand, Luna and Wu (Luna \& Wu, 2000) suggested simulating RCC dams in low-temperature seasons, where it is possible to use a lesser quantity of cement in comparison to the CC dam, which ultimately reduces peak temperature, thermal stresses, and prevent development of thermal cracks.

\section{Seismic Behavior of RCC Dams}

Ghaedi et al. (Ghaedi et al., 2016) performed a nonlinear time history analysis for Kinta RCC dam in Malaysia. Their findings present that small stresses in the dam are noticeably growing when large openings are considered in modeling of RCC dam's cross-section. The pattern and propagation of crack are affected by the size and shape of the gallery, where circular one provides an enhanced damage response in comparison to square and octagon. Cheng and Zhang (Cheng \& Zhang, 2012) reported that upper, lower, and middle parts of the arch crown are often the weakest portions under earthquake. Moreover, for any seismic resisting high arch dam project, only a nonlinear foundation should be taken into 
account. Gharibdoust et al. (Gharibdoust et al., 2019) conducted an experimental study composed of a pushover and dynamic at the Operational Based Earthquake (OBE), the Maximum Design Earthquake (MDE) and the Maximum Credible Earthquake (MCE) levels on a scaled specimen of RCC dam with rough and smooth bases. The results have shown that the roughened base specimen did not exhibit sliding motion, but the specimen with a smooth base undergone sliding displacements up to $70 \%$ of the total tip displacement which produced less cracks as shown in Figure 12 . Although the slipping and inclined body cracking are unacceptable, appropriate treatment of the dam base foundation interface should be introduced due to its significant impact on seismic behavior and crack propagation in gravity dams.

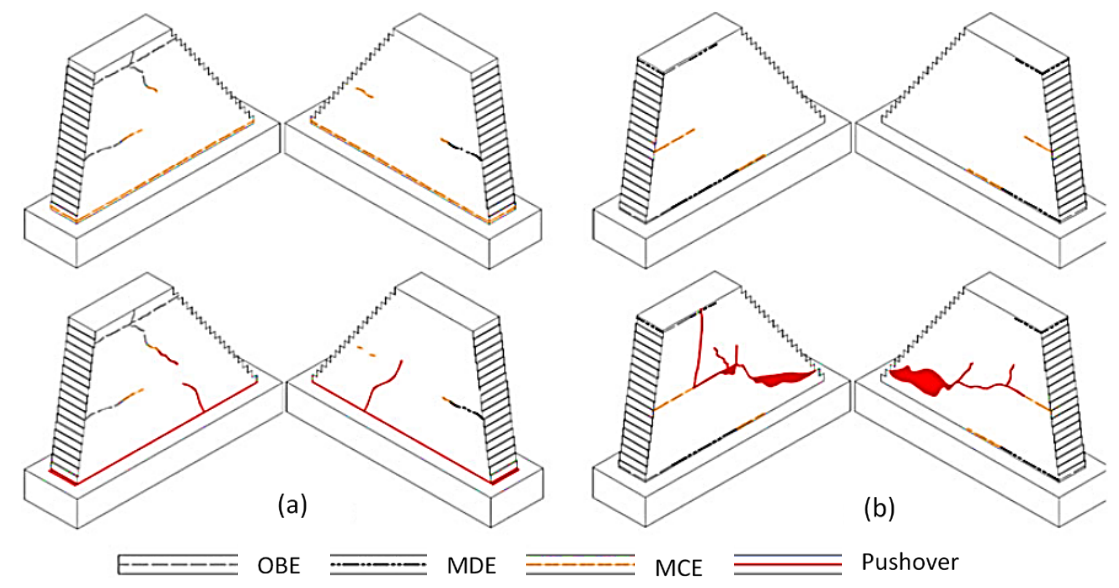

Figure 12: Crack propagation patterns: (a) smooth base (SB) and (b) roughened base (RB) (Gharibdoust et al., 2019)

From their numerical study, the coefficient of friction changes in accordance with the load history, and its value seems like a substantial challenge to be calculated since it helps in defining the dam's failure mode. Zhang et al. (L. Zhang et al., 2019a) mentioned that in comparison to the dam body, its foundation faces greater damage under the cumulative effect of the main aftershock, as shown in Figure 13.

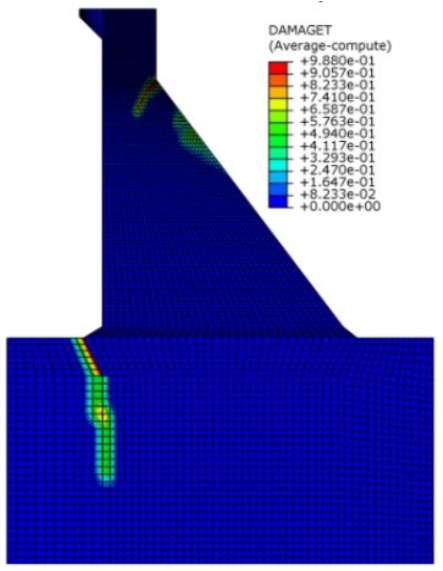

(a)

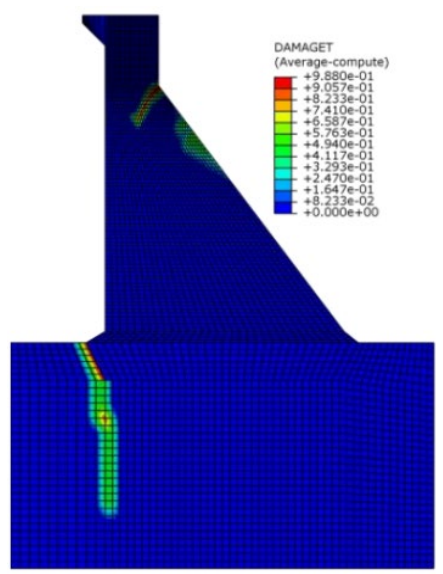

(b)

Figure 13: Dam induced damage: (a) mainshock; (b) combined mainshock and aftershock (L. Zhang et al., 2019a)

\section{CONCLUSION}

This paper has focused on reviewing available studies in the field of RCC dams. On the bases of the above statements, the following points are drawn:

- Two types of RCC dams, according to their design and structural system, are mainly constructed, which are the gravity dam and the arch one each with has several advantages and disadvantages.

- Commercial FE software packages are capable of estimating the stresses and response of RCC dams under thermal and seismic actions.

- The crack index is a good indicator of the failure occurring probability in RCC dams. 
- The heat in RCC dams is gradually raised during the early stage of casting and increases significantly in the following early few days.

- Opening in the cross-section of the dam remarkably increases the stress applied due to seismic actions.

Currently, the literature presents a rich content about the FE modeling of RCC dams and its behavior under thermal effects. However, more information regarding its performance under earthquake excitations is still required and needs to be discussed in detail to highlight points like the expected failure modes and the possible mitigation strategies.

Author's Contribuitions: Conceptualization, A Habib, A Al Houri, and M Habib; Writing - original draft, A Habib, A Al Houri, and A Elzokra; Writing - review \& editing, M Habib and U Yildirim.

Editor: Marcílio Alves.

\section{References}

Abaqus. (2010). Abaqus theory manual. Abaqus Inc.

Abdulrazeg, A. A., Noorzaei, J., Jaafar, M. S., Khanehzaei, P., \& Mohamed, T. A. (2014). Thermal and structural analysis of RCC double-curvature arch dam. Journal of Civil Engineering and Management, 20(3), 434-445.

Abdulrazeg, A. A., Noorzaei, J., Khanehzaei, P., Jaafar, M. S., \& Mohammed, T. A. (2010). Effect of temperature and creep on roller compacted concrete dam during the construction stages. Computer Modeling in Engineering and Sciences (CMES), 68(3), 239-268.

ACl. (1985). Cement and concrete terminology.

ACl. (1995). ACl 325.10 R: Roller-compacted concrete pavements.

ACl. (2005). ACl 207.1 R-05: Guide to mass concrete.

ACI. (2011). ACl207.5R-11: Report on Roller-Compacted Mass Concrete.

ACI. (2013). ACI CT-13: ACl Concrete Terminology.

Aghaeipour, A., \& Madhkhan, M. (2019). Mechanical properties and durability of roller compacted concrete pavement (RCCP)-a review. Road Materials and Pavement Design, 1-24.

Al Baghdady, S., \& Khan, L. (2018). Designing Roller compacted concrete (RCC) dams. KTH ROYAL INSTITUTE OF TECHNOLOGY.

Al Houri, A., Habib, A., Elzokra, A., \& Habib, M. (2020). Tensile Testing of Soils: History, Equipment and Methodologies. Civil Engineering Journal, 6(3), 591-601.

Ansys. (2012). Swanson Analysis Systems Inc.

Arici, Y., Binici, B., \& Aldemir, A. (2014). Comparison of the expected damage patterns from two-and three-dimensional nonlinear dynamic analyses of a roller compacted concrete dam. Structure and Infrastructure Engineering, 10(3), 305-315.

Armanpour, A., \& Tajdini, M. (2016). An Introduction to Rolling Compacted Concrete (RCC) in Construction of Roads. Bulletin de la Société Royale des Sciences de Liège, 85, 735-740.

Army, U. (1987). TM 5-822-7: Standard Practice for Concrete Pavements. United States Department of the Army.

Army, U. (2000). Roller-Compacted Concrete. United States Department of the Army.

Army, U. (2006). Roller compacted concrete, EM 1110-2-2006.

Ashtankar, V. B., \& Chore, H. S. (2014). Development of design mix roller compacted concrete dam at Middle Vaitarana. Advances in concrete construction, 2(2), 125-144.

Atiş, C. D. (2005). Strength properties of high-volume fly ash roller compacted and workable concrete, and influence of curing condition. Cement and Concrete Research, 35(6), 1112-1121. 
Bauchkar, S. D., \& Chore, H. S. (2012). Roller compacted concrete: A literature review. IOSR Journal of Mechanical and Civil Engineering, 28-32.

Bayagoob, K. H. (2008). Thermal and Structural Analysis of RCC Dams. Ph.D. Thesis. University Putra Malaysia.

Bayagoob, K. H., \& Bamaga, S. O. (2019). Construction of Roller Compacted Concrete Dams in Hot Arid Regions. Materials, 12(19).

Broberg, L., \& Thorwid, M. (2015). Evaluation of failure modes for concrete dams. KTH Royal Institute of Technology.

Chen, H., \& Liu, Z. (2019). Temperature control and thermal-induced stress field analysis of GongGuoQiao RCC dam. Journal of Thermal Analysis and Calorimetry, 135(4), 2019-2029.

Chen, Y., Wang, C., Li, S., Wang, R., \& He, J. (2001). Simulation analysis of thermal stress of RCC dams using 3-D finite element relocating mesh method. Advances in engineering software, 32(9), 677-682.

Chen, Y. L., Wang, C. J., Li, S. Y., \& Chen, L. J. (2003). The effect of construction designs on temperature field of a roller compacted concrete dam - a simulation analysis by a finite element method. Canadian Journal of Civil Engineering, 30(6), 1153-1156.

Cheng, H., \& Zhang, L. (2012). Study on Ultimate Anti-Seismic Capacity of High Arch Dam. Journal of Aerospace Engineering, 26(4), 648-656.

Chhorn, C., Hong, S. J., \& Lee, S. W. (2018). Relationship between compressive and tensile strengths of roller-compacted concrete. Journal of Traffic and Transportation Engineering (English Edition), 5(3), 215-223.

Chi, M., \& Huang, R. (2014). Effect of circulating fluidized bed combustion ash on the properties of roller compacted concrete. Cement and Concrete Composites, 45, 148-156.

Choi, Y. K., \& Groom, J. L. (2001). RCC mix design-soils approach. Journal of materials in Civil Engineering, 13(1), 71-76.

Courard, L., Michel, F., \& Delhez, P. (2010). Use of concrete road recycled aggregates for Roller Compacted Concrete. Construction and Building Materials, 24(3), 390-395.

DEQ. (2007). Dam operation, maintenance, and inspection manual. Department of Environment and Natural Resources.

Dunstan, M. (2003). The state-of-the-art of RCC dams in 2003-an update of ICOLD bulletin No. 125. 4th International Symposium on Roller Compacted Concrete Dams, MADRID.

Fang, C. H., Chen, J., Duan, Y. H., \& Xiao, K. (2017). A new method to quantify breach sizes for the flood risk management of concrete arch dams. Journal of Flood Risk Management, 10(4), 511-521.

FERC. (2002). Chapter III Gravity Dams. In Engineering guidelines for evaluation of hydropower projects. Federal Energy Regulatory Commission, Office of Hydropower Licensing. .

Ghaedi, K., Jameel, M., Ibrahim, Z., \& Khanzaei, P. (2016). Seismic analysis of Roller Compacted Concrete (RCC) dams considering effect of sizes and shapes of galleries. KSCE Journal of Civil Engineering, 20(1), 261-272.

Gharibdoust, A., Aldemir, A., \& Binici, B. (2019). Seismic behaviour of roller compacted concrete dams under different base treatments. Structure and Infrastructure Engineering, 1-12.

Gu, C. S., Wei, B. W., Xu, Z. K., \& Liu, D. W. (2013). Fluid-solid coupling model based on endochronic damage for roller compacted concrete dam. Journal of Central South University, 20(11), 3247-3255.

Habib, A., Yildirim, U., \& Eren, O. (2020). Column repair and strengthening using RC jacketing: a brief state-of-the-art review. Innovative Infrastructure Solutions, 5(3), 75.

Hansen, K. D., \& Reinhardt, W. G. (1991). Roller-compacted concrete dams. McGraw-Hill.

Harrington, D., Abdo, F., Adaska, W., Hazaree, C. V., Ceylan, H., \& Bektas, F. (2010). Guide for roller-compacted concrete pavements. National Concrete Pavement Technology Center.

Heirany, Z. (2017). Seismic Behavior of RCC Dams Including the Effect of Foundation. Journal of Applied Engineering Sciences, $7(2), 39-43$.

Hu, W., Zhong, D., Wu, B., \& Li, Z. (2019). Construction phase oriented dynamic simulation: taking RCC dam placement process as an example. Journal of Civil Engineering and Management, 25(7), 654-672. 
Huang, Y., \& Wan, Z. (2018). Study on Viscoelastic Deformation Monitoring Index of an RCC Gravity Dam in an Alpine Region Using Orthogonal Test Design. Mathematical Problems in Engineering.

Husein Malkawi, A. I., Aufleger, M., \& Al-Jammal, M. R. (2004). Temperature distribution in Al-Mujib roller compacted concrete (RCC) gravity dam. In Geo Jordan 2004: Advances in Geotechnical Engineering with Emphasis on Dams, Highway Materials, and Soil Improvement,

Husein Malkawi, A. I., Mutasher, S. A., \& Qiu, T. J. (2003). Thermal-structural modeling and temperature control of roller compacted concrete gravity dam. Journal of performance of constructed facilities, 17(4), 177-187.

ICOLD. (1995). Dam failures statistical analysis. International Commission on Large Dams (ICOLD), Bulletin 99.

J. G. M., v. M. (1997). Fracture process of concrete: Assessment of material parameters for fracture models. CRC Press, Inc.

Jaafar, M. S., Bayagoob, K. H., Noorzaei, J., \& Thanoon, W. A. M. (2007). Development of finite element computer code for thermal analysis of roller compacted concrete dams. Advances in Engineering Software, 38(11-12), 886-895.

Jia, C., Shao, A., Li, Y., \& Ren, Q. (2010). Analyses of thermal stress field of high concrete dams during the process of construction. In 2010 Asia-Pacific Power and Energy Engineering Conference, Chengdu, PEOPLES R CHINA.

Jiang, S., Zhan, S. L., \& Xiao, N. (2013). Influence of casting temperature and solar radiation on the thermal field in roller compacted concrete during construction. Applied Mechanics and Materials, 405-408, 2550-2554.

Kartal, M. E. (2012). Three-dimensional earthquake analysis of roller-compacted concrete dams. Natural Hazards and Earth System Sciences, 12(7), 2369-2388.

Khanzaei, P., Abdulrazeg, A. A., Samali, B., \& Ghaedi, K. (2015). Thermal and structural response of RCC dams during their service life. Journal of Thermal Stresses, 38(6), 591-609.

Kokubu, K., Cabrerab, J. G., \& Uenoa, A. (1996). Compaction Properties of Roller Compacted Concrete.

Kuzmanovic, V., Savic, L., \& Mladenovic, N. (2013). Computation of thermal-stresses and contraction joint distance of RCC dams. Journal of Thermal Stresses, 36(2), 112-134.

Kuzmanović, V., Savić, L., \& Mladenović, N. (2015) . Thermal-stress behaviour of RCC gravity dams. FME Transactions, 43(1), 30-34.

Lampropoulos, A. P., \& Dritsos, S. E. (2011). Concrete shrinkage effect on the behavior of RC columns under monotonic and cyclic loading. Construction and Building Materials, 25(4), 1596-1602.

Li, M. C., Guo, X. Y., Shi, J., \& Zhu, Z. B. (2015). Seepage and stress analysis of anti-seepage structures constructed with different concrete materials in an RCC gravity dam. Water Science and Engineering, 8(4), 326-334.

Li, S., Ren, J., Yang, T., \& Chen, P. (2010). Analysis of the Influence of Concrete Mixed with MgO on the Mass Concrete Thermal Stress. In 2010 Asia-Pacific Power and Energy Engineering Conference, Chengdu, PEOPLES R CHINA.

Liapichev, Y. P. (2003). Seismic stability and stress-strain state of a new type of FSH-RCC dams. 4th International Symposium on Roller Compacted Concrete Dams, MADRID.

Liu, G., Lu, W., Lou, Y., Pan, W., \& Wang, Z. (2018). Interlayer shear strength of Roller compacted concrete (RCC) with various interlayer treatments. Construction and Building Materials, 166, 647-656.

Luna, R., \& Wu, Y. (2000). Simulation of temperature and stress fields during RCC dam construction. Journal of Construction Engineering and Management, 126(5), 381-388.

Mohammed, H. A. (2018). Design and evaluation of two-layer roller compacted concrete. University of Nottingham.

Mughieda, O., Hazirbaba, K., Bani-Hani, K., \& Daoud, W. (2018). Numerical modelling of dynamic stability of RCC dam. In MATEC Web of Conferences, Solo Baru, INDONESIA.

Nagayama, I., \& Jikan, S. (2003). 30 Years' History of Roller-compacted Concrete Dams in Japan. Fourth Int. Symp. on Roller Compacted Concrete Dams,

Noorzaei, J., Bayagoob, K. H., Thanoon, W. A., \& Jaafar, M. S. (2006). Thermal and stress analysis of Kinta RCC dam. Engineering Structures, 28(13), 1795-1802.

PCA. (2003). Design Manual for Small RCC Dams. Portland Cement Association. 
Pedro, J. O. E. (2014). Arch dams: Designing and monitoring for safety (Vol. 367). Springer.

Perumal, L., \& Mon, D. T. T. (2011). Finite elements for engineering analysis: a brief review. In Proceedings of the International Conference on Modeling, Simulation and Control, Singapore.

Punmia, B. C., Lal, P. B. B., Jain, A. K., \& Jain, A. K. (2009). Irrigation and water power engineering. Laxmi Publications, Ltd.

Rao, S. K., Sravana, P., \& Rao, T. C. (2016a). Abrasion resistance and mechanical properties of Roller Compacted Concrete with GGBS. Construction and Building Materials, 114, 925-933.

Rao, S. K., Sravana, P., \& Rao, T. C. (2016b). Investigating the effect of M-sand on abrasion resistance of Roller Compacted Concrete containing GGBS. Construction and Building Materials, 122, 191-201.

Rongmei, J., \& Wei, F. (2007). Impact of Interlayer and Size Effect on the Mechanical Performances of Fully Graded RCC. Water Power, 4.

Rooholamini, H., Hassani, A., \& Aliha, M. R. M. (2018). Fracture properties of hybrid fibre-reinforced roller-compacted concrete in mode I with consideration of possible kinked crack. Construction and Building Materials, 187, 248-256.

Saleh, S. F., Rather, F. F., \& Jabbar, M. J. (2017). Roller-compacted concrete (RCC) and its application in modern world of Technology. International Research Journal of Engineering and Technology 4(4).

Sha, S., Lei, Z., \& Zhang, X. (2016). Study on failure mechanism of roller compacted concrete gravity dams by an isotropic damage model. International Conference on Smart City and Systems Engineering (ICSCSE), IEEE.

Shamsai, A., Ghaemian, M., \& Azimfar, S. M. (2009). Thermo-Mechanical Analysis of Roller Compacted Concrete (RCC) Dams (Jahgin Dam). In Symposium on the Application of Geophysics to Engineering and Environmental Problems,

Su, H., Wen, Z., Yan, X., Liu, H., \& Yang, M. (2018). Early-warning model of deformation safety for roller compacted concrete arch dam considering time-varying characteristics. Composite Structures, 203, 373-381.

Su, P. F., Wang, W. M., \& Lu, X. L. (2011). STUDY ON SAFETY EVALUATION METHODS AND FAILURE MECHANISM OF HIGH ROLLER COMPACTED CONCRETE DAM. In Engineering Plasticity And Its Applications, 275-280.

Tschuchnigg, F., \& Schweiger, H. (2014). 3D Finite Element analysis of a RCC dam. In 8th European Conference on Numerical Methods in Geotechnical Engineering, Balkema.

Tun, Z. P., Kyaw, N. M., \& Htwe, K. S. S. (2016). Properties of Roller Compacted Concrete with Pozzolan as Cement Replacement Material. INTERNATIONAL JOURNAL FOR INNOVATIVE RESEARCH IN MULTIDISCIPLINARY FIELD 2(12), $247-255$.

Wang, J., \& Chopra, A. K. (2008). EACD-3D-2008: A computer program for three-dimensional earthquake analysis of concrete dams considering spatially-varying ground motion. Earthquake Engineering Research Center.

Wang, J., Jin, F., \& Zhang, C. (2011). Seismic safety of arch dams with aging effects. Science China Technological Sciences, 54(3), 522-530.

Wang, C., Chen, W., Hao, H., Zhang, S., Song, R., \& Wang, X. (2018a). Experimental investigations of dynamic compressive properties of roller compacted concrete (RCC). Construction and building materials, 168, 671-682.

Wang, L., Zhang, G., Wang, P., \& Yu, S. (2018b). Effects of fly ash and crystalline additive on mechanical properties of twograded roller compacted concrete in a high RCC arch dam. Construction and Building Materials, 182, 682-690.

Wang, Q., Huang, Z., \& Wang, D. (2018c). Influence of high-volume electric furnace nickel slag and phosphorous slag on the properties of massive concrete. Journal of Thermal Analysis and Calorimetry, 131(2), 873-885.

Warren, T. (2012). Roller Compacted Concrete for Dam Construction. Volume, 22, 87-90.

Warren, T. (2013). Roller-compacted concrete dams: a brief history and their advantages. Dams and Reservoirs, 22(2), 87-90.

Willam, K. J., \& Warnke, E. D. (1975). Constitutive model for the triaxial behavior of concrete. Proceedings of International Association for Bridge and Structural Engineering, Bergamo, Italy.

Wilson, E. L., \& Habibullah, A. (1989). SAP90: A Series of Computer Programs for the Static and Dynamic Finite Element Analysis of Structures: Users Manual. Computers \& Structures, Incorporated.

Xia, S. F. (2017). Simulation analysis of temperature control on RCC arch dam of hydropower station. In IOP Conference Series: Earth and Environmental Science, Singapore, SINGAPORE. 
Xie, H., \& Chen, Y. (2005). Determination of the type and thickness for impervious layer in RCC dam. Advances in Engineering Software, 36(8), 561-566.

Yahui, D., \& Guowei, L. (1995). Study on failure mechanism of roller compacted concrete fravity dam. Journal of Hydraulic Engineering, 5, 55-59.

Yang, L., \& Shi, J. J. (2009). Experimental study on the impact of rainfall on RCC construction. Journal of Construction Engineering and Management, 136(5), 477-483.

Zarrin, O., Shirazi, M. R., Moniri, H., \& Moniri, M. (2016). Roller-compacted concrete dams rehabilitation in terms of different problem. Journal of Civil \& Environmental Engineering, 6(2), 1-4.

Zhang, L., Zhai, Y., Chen, D., \& Cui, X. (2019a). Study on influence of dam foundation damage on seismic safety of gravity dam under combined action of main shock and aftershock. In IOP Conference Series: Earth and Environmental Science,

Zhang, X., Shi, R., Dai, H., Liu, Q., \& Zhang, X. (2019b). Simulation and Research on Temperature Field of Taishan Roller Compacted Concrete Gravity Dam. In IOP Conference Series: Earth and Environmental Science, Chengdu, PEOPLES R CHINA.

Zhang, X., Zhang, X., Yan, T., Huang, Y., Liu, Q., \& Wang, X. (2019c). Experimental analysis and numerical calculation on equivalent strength of induced joints of different ages and weakening degrees. Journal of the Ceramic Society of Japan, 127(9), 642-650.

Zhang, X. F., Li, S. Y., Li, Y. L., Ge, Y., \& Li, H. (2011). Effect of superficial insulation on roller-compacted concrete dams in cold regions. Advances in Engineering Software, 42(11), 939-943.

Zheng, X., Zhou, J., Chen, G., \& Chen, S. (2020). Exposure Assessment for Roller Compacted Concrete Dam Construction Integrated Real-Time Location Information. KSCE Journal of Civil Engineering, 24(3), 703-714.

Zhou, H., Zhou, Y., Zhao, C., \& Liang, Z. (2016). Optimization of the temperature control scheme for roller compacted concrete dams based on finite element and sensitivity analysis methods. Civil Engineering Journal-Stavebni Obzor, 3(14), 1-16. 